\title{
ROLE HODNOT V ORGANIZAČNÍ KULTUŘE ${ }^{1}$
}

\section{Lenka Černohorská}

Klíčová slova: Organizační kultura, axiologické, neontologické, korporátní hodnoty.

Key words: Organization Culture, axiological, neontological, corporate Values.

\begin{abstract}
Abstrakt
V posledních letech nabývá na rostoucím významu a popularitě téma organizační kultury, jakožto zdroje konkurenční výhody. Následující článek se zabývá definicí, hodnocením a důležitostí pojmu organizační kultura, prvky organizační kultury a důležitostí hodnot $\mathrm{v}$ organizační kultuře. V souvislosti s výhodami existence pozitivní kultury a prvků organizační kultury, jsou prezentovány první výsledky výzkumu důležitosti hodnot organizací mezi českými firmami a jejich rozbor, jenž v komparaci s hlavními atributy podnikatelského prostředí představuje zajímavé zjištění a závěry.
\end{abstract}

\begin{abstract}
AJ)
During last decade is become concept of corporate culture important and popular topic as a source of competitive advantage. Following paper is focused on short theoretical analysis and definition of corporate culture term; main elements of organizational culture and importance of values in organizational culture. Within the context of existence advantages of positive corporate culture and organizational culture elements, are presented first survey's results between Czech firms. Research shows importance of organizational values, which are in comparison with mains attributes of entrepreneurship environment indicate interesting findings and conclusions.
\end{abstract}

\section{Úvod}

Organizační kultura se stala důležitým tématem $\mathrm{v}$ podnikání zejména $\mathrm{v}$ posledních dvou desetiletích. Přestože je organizační kultura nehmotný koncept, hraje významnou úlohu ve společnostech, protože ovlivňuje zaměstnance a organizační opatření v celém podniku. Kultura není jen faktorem podnikatelského úspěchu či neúspěchu, pozitivní kultura může být významnou konkurenční výhodu.

Organizační kultura začala být studována a oceňovaná v USA na přelomu 70-80 let 19. století. Velký význam měla kniha s názvem Corporate Cultures: The Rites and Rituals of Corporate Life (Deal, Kennedy, 1982). Autor popularizoval ponětí a porozumění o pozitivní organizační kultuře. Za méně než dvě desetiletí od doby, kdy tato kniha vyšla, se pojem kultury změnil z poměrně neznámého pojmu až na pojem, který je nyní uznávaný, a který hraje významnou roli $\mathrm{v}$ podnikové strategii. Doslova stovky knih a tisíce článků bylo věnováno tomuto tématu. Je zřejmé, že organizační kultura se stala důležitým aspektem pro vrcholový management, a proto je důležité podrobně prozkoumat a porovnat jednotlivé př́stupy a definice organizační kultury.

\footnotetext{
${ }^{1}$ Článek je jedním z výstupů specifického výzkumu VUT v Brně BD 17001004
} 


\section{Definice organizační kultury}

Existuje mnoho zpo̊sobů, jak definovat organizační kulturu, protože je ovlivňována faktory, jako je odvětví, ve kterém společnost působí, její geografické umístění, události, které nastaly během její historie, osobnosti svých zaměstnanců, a jejich vzory interakce. Některé z formálních definic vymezují kulturu takto: kognitivní rámec, který se skládá z postojů, hodnot, norem chování a očekávání (Greenberg, Baron, 1997), kolektivní myšlení, zvyky, postoje, pocity a vzorce chování (Clemente, Greenspan, 1999), programovaný způsob vnímání odvozený z názorů a hodnot (Hall, 1995), vzor uspořádání, materiálu nebo chování, který byl přijat společností za přijatelný způsob, jak řešit problémy (Ahmed et al., 1999) a základní hodnoty, názory a přesvědčení, které existují v organizaci, vzorce chování, které jsou důsledkem těchto sdílených významů, které vyjadřují spojení mezi přesvědčeními, hodnotami a chováním členů organizace (Denison, 1990).

Pokud zobecníme předložené definice organizační kultury, můžeme tvrdit, že organizační kulturu lze posuzovat jako:

- soubor základních přesvědčení, hodnot, postojů a norem chování,

- které jsou sdíleny $\mathrm{v}$ rámci organizace $\mathrm{a}$

- které se projevují v myšlení, cítění a chování členů organizace a v artefaktech materiální a nemateriální povahy (Lukášová, 2010).

Dnes se v teorii o organizačních kulturách klade důraz na následující charakteristiky: kultura zaměřená ven oproti kultuře zaměřené dovnitř, kultura posilující individuální kompetence oproti kultuře centralizované, kultura s rychlým rozhodováním oproti pomalému rozhodování, kultura př́stupnější riskantním krokům oproti kultuře vyhýbající se rizikům (Kotter, 2000 podle Franková, 2003). V současném globalizovaném prostření, kdy lidé přicházejí z různých etnických prostředí a kulturní dědictví, mají různé osobnosti, a byly utvářeny pestrou škálou zážitků, jsou sdruženi v pracovním prostředí. Tyto faktory se projevují nekonečně mnoha způsoby.

Organizační kultura nemůže existovat bez rozsáhlé podpory zaměstnanců. I v rámci organizace, která má dominantní kulturou, bude také existovat mnoho subkultur (Greenberg a Baron, 1997). Ty mohou vznikat $\mathrm{z}$ mnoha důvodů, např. kvůli rozdílným úsekům v organizaci (finance, prodej, marketing), nebo k etnickým či geografickým rozdílům mezi zaměstnanci. Dominantní kultura $\mathrm{v}$ organizaci musí být dostatečně silná, pro členy různých subkultur $\mathrm{v}$ rámci organizace, kteří se s ní identifikují a dokážou ji přijmout. To nezbytně vyžaduje, aby hodnoty převládající kultury byly v souladu s hodnotami jednotlivých subkultur, stejně jako osobní hodnoty každého jednotlivce.

\section{Výhody pozitivní organizační kultury}

U organizace, která je schopna udržovat organizační kulturu, je velmi pravděpodobné, že bude mít mnoho výhod. Zaměstnanci, kteří se ztotožňují s kulturou, vytvářejí př́ijemné pracovní prostředí, které má tendenci zvýšit etiku. To vede ke zvýšení týmové práce, sdílení informací a otevřenosti vůči novým myšlenkám (Goffee, Jones, 1996).

Zvýšená interakce mezi zaměstnanci aktivuje vzdělávání a neustálé zlepšování, protože informační toky proudí $\mathrm{v}$ celé organizaci. Navíc taková kultura pomáhá přilákat a udržet špičkové zaměstnance (Greger, 1999). 
Pozitivní organizační kultura obvykle zahrnuje několik klíčových prvků:

1. Kultura podporuje nejen poslání, ale jasnou vizi společnosti, která je obrazem společnosti. (Qubein, 1999). Firemní vize jsou nejúčinnější, když jasně sděleny top manažerům, kteří vykazují silné hodnoty a mají dynamické a charismatické osobnosti (Greenberg a Baron, 1997).

2. Organizační kultura je podporována firemními hodnotami, které jsou v souladu společnosti a jsou slazeny $\mathrm{s}$ osobními hodnotami členů organizace (Qubein, 1999). Firemní vize a hodnoty prostupují všechny úrovně organizace a jsou trvale utvářeny top managementem.

3. Zaměstnanci jsou oceněni na všech úrovních organizace (Clemente, Greenspan, 1999).

4. Kultura umožňuje rychlou změnu na vnější podmínky a je konzistentní a ke všem zaměstnancům stejně transparentní (Ahmed et al., 1999).

5. Organizační kultura se uchová způsobem, např. prostřednictvím konkrétních značek, sloganů, které zdůrazňují firemní hodnoty (Greenberg a Baron, 1997).

\section{Prvky organizační kultury}

Za prvky organizační kultury bývají nejčastěji považovány nejjednodušší strukturální a funkční jednotky, které představují základní skladební komponenty kulturního systému. Prvky organizační kultury nebývají autory vymezeny a kategorizovány zcela jednotně, avšak nejčastěji jsou za prvky kultury považovány: základní přesvědčení, hodnoty, normy, postoje a dále vnější manifestace kultury, které bývají označovány, jako artefakty materiální a nemateriální povahy (Lukášová, 2010).

Prvky organizační kultury nefungují izolovaně, ale vzájemně se ovlivňují a spolu souvisí, proto se někteří autoři snažili vytvořit modely organizační kultury (viz. obr. č. 1).

\section{Obr. č. 1: Model organizační kultury}

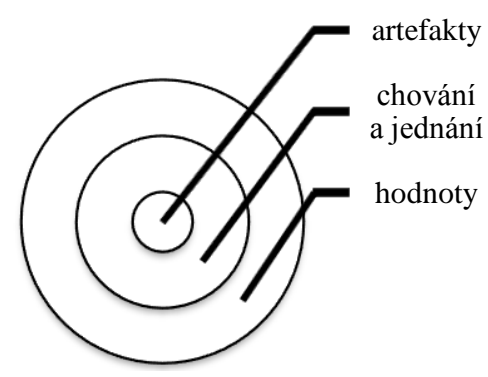

Zdroj: Vlastní zpracování na základě teorie W. Halla.

\section{Hodnoty}

Jedním z klíčových prvků organizační kultury jsou hodnoty, jejichž vymezení může být následující: Vymezení hodnoty může být následující: „Hodnoty znamenají vlastnost nějakého předmětu, jevu, myšlenky, vztahu, lidského jednání apod., spočívající v uspokojování některé z lidských potřeb. Hodnotou se stává to, co hraje zásadní úlohu v našem životě, myšlení, prožívání a rozhodování“ (Nesvadba, 2006). Hodnoty jsou důležitou součástí každého jednotlivce. Jsou to základní přesvědčení - základní myšlenky, které stimulují lidské chování. 
Hodnoty můžeme specifikovat $\mathrm{z}$ pohledu axiologického, ale také deontologického, kde do popředí vystupuje především rovina normativní (Putnová, Seknička, 2008). Rokeach (1973) definoval jako normativní hodnoty, trvalé normy, které mají kognitivní, afektivní a behaviorální složky. Přestože hodnoty jsou považovány za normativní, hrají důležitou roli při rozhodování, které činíme. Hodnoty jsou trvalé standardy, které společně tvoří hodnotové systémy našeho života (Russell, 2000). Pro podnikatelský proces je důležitá jak pragmatická rovina, tj. orientace na činnostní stránku, ale i konkrétní situaci, tak ideová rovina, která je základem obsahu vize a strategie podnikání. Pro kvalitní rozhodování v podnikatelském procesu jsou důležité obě zmíněné roviny, nebot' nám není lhostejná vůle k životu ani ideje obecného žití. Obě roviny jsou klíčové pro vytváření hodnotových soudů (Putnová, Seknička, 2008).

Hodnoty nám stanovují limity dobra a zla ve společenských aktivitách, přičemž jejich základem je proces kulturní relativizace hodnot. Takové hodnoty pak můžeme chápat jako vztahové kvality, tj. něco je dobré nebo špatné ve vztahu $\mathrm{k}$ něčemu nebo k někomu. Člověk může mít různé představy o tom co je dobré a co je špatné, ale v konkrétní společnosti jedna hodnota převládá, což se často označuje jako ,hodnotová dohoda“. Jednotlivé skupiny hodnot nejsou zcela v souladu, tj. existují mezi nimi tenze. V podnikatelském procesu tyto tenze vznikají mezi hodnotami společenskými, podnikovými, osobními a profesními, blíže viz obr. č. 2 (Putnová, Seknička, 2008).

\section{Obr. č. 2 - Tenze mezi základními skupinami hodnot}

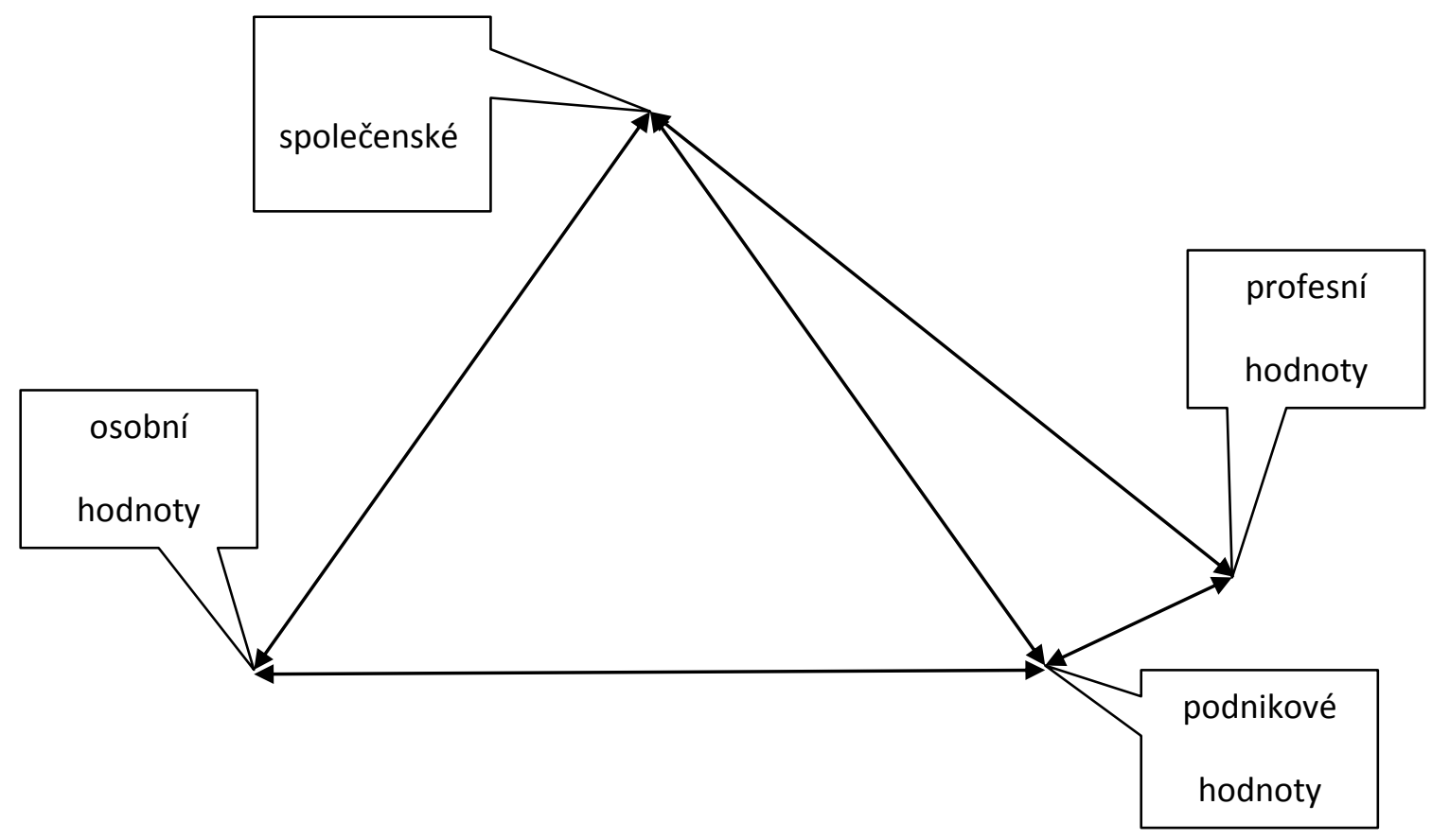

Zdroj: Putnová, Seknička,Uhlář, 2008

Organizační kultury konsolidují sdílené přesvědčení, předpoklady, cíle a hodnoty jejich členů. Sdílené hodnoty organizací přispívají k trvalému úspěchu organizací. Většina hodnot pochází od nadřízeného a proniká do všech úrovní organizace. Podnikové hodnoty by měly dát každému zaměstnanci vnitřní kompas, který jim umožní jednat samostatně a ve vzájemné závislosti, odpovědně. (Rusell, 2001). 
Organizační hodnoty, stejně jako osobní hodnoty, mohou být dobré nebo špatné. Organizace mohou implicitně či explicitně, vědomě či nevědomě přijmout hodnoty, které se navzájem doplňují, nebo které jsou mezi sebou v rozporu. Kromě toho mohou dobré organizační hodnoty časem zanikat. Konflikty a kompromisy mohou způsobit posunu organizační hodnoty ve špatném směru, nebo špatní vůdci mohou záměrně měnit a upravovat ústřední hodnoty organizace (Malphurs, 1996).

\section{Empirické šetření}

Cílem předložené studie je shrnout a popsat některá ze zjištění v rámci dotazníkového šetření a diskutovat současnou úroveň řízení organizační kultury v podnikové praxi.

Cílem dotazníkového šetření, které bylo zaměřené na firmy Jihomoravského kraje, bylo analyzovat jejich zkušenosti, názory a očekávání týkající korporátních hodnot, etiky a podnikové kultury. Formulovali jsme si tři dílčí cíle. Prvním cílem bylo prozkoumat zkušenosti a uplatňování organizační kultury firem Jihomoravského kraje. Dále jsme se zaměřili na zjištění korporátních a etických hodnot vztahujících se $\mathrm{k}$ jejich oboru podnikání. Třetí oblast zkoumání byla zaměřena na konkurence schopnost ve vztahu k organizační kultuře a procesního rrízení.

Byly formulované hypotézy, které jsou propojeny s cíli dotazníkového šetření, jejichž zodpovězení naplní definované cíle.

Hypotéza 1:

Organizační kultura je uplatňována především ve velkých podnicích.

Hypotéza 2:

Organizace nepovažuji hodnoty za významné

Hypotéza 3:

Podniky v Jihomoravském kraji nevnímají organizační kulturu jako zdroj konkurenční výhody

\section{Metodologie}

Na základě výsledků předchozích výzkumů (Putnová, Seknička, 2007; Blažek, L., 2007 atd.) zaměřených na konkurenceschopnost podniků, postoje $\mathrm{k}$ hodnotám a $\mathrm{k}$ organizační kultuře, jsme sestavili dotazník, který pokrýval základní tři oblasti výzkumu (viz výše) a obsahoval baterii 21 otázek.

V průběhu měsíců záŕí až prosinec roku 2010 proběhlo dotazníkové šetření na vybraných Jihomoravského kraje. Jednalo se o dotazníkové šetření provedené na vzorku 200 firem, a to především středních a velkých firem. Empirického šetření se zúčastnilo 136 velkých a 74 středních firem. Podle dělení Komise Evropského společenství do kategorie středních podniků patř́i podniky, ve kterých je zaměstnáno méně než 250 zaměstnanců a více než 50 a jejichž roční obrat nepřesahuje 50 milionů eur. Jestliže podnik zaměstnává více než 250 zaměstnanců a jeho roční obrat je vyšší než 50 milionů eur, spadá do kategorie velký podnik.

Dotazník byl anonymní, identifikace respondentů byla jen obecná (velikost podniku, obor podnikání) 
Z pohledu sledovaného základního souboru (firmy Jihomoravského kraje) a sledovaných znaků jeho jednotek (souhrnně a stručně řečeno: organizační kultura a procesní řízení, korporátní a etické hodnoty, konkurence schopnost) bylo významným primárním krokem vhodně zvolit tzv. výběr (vzorek; výzkum nebylo možné samožrejmě realizovat u celého základního souboru, což je podstatou statistických metod) tak, aby byl dostatečně reprezentativní pro tento typ (aby poskytoval informace co nejvíce bez omezení) a dále pokud možno dostatečně homogenní (aby poskytoval informace bez vlivu dalších faktorů). Protože tyto vlastnosti nemusí být vždy verifikovaně zajištěny, obvykle výběr bývá prováděn náhodně (s vědomím rizika, že informace o základním souboru mohou být určitou měrou zkresleny). V př́padě tohoto projektu šlo o výběr bez opakování (žádný respondent nemohl vyplňovat více než jeden dotazníkový arch), v jistém slova smyslu byl záměrný (byli osloveni respondenti se velkých i středních firem).

V etapě statistického šetření byl tedy navržen a zvolen výběrový soubor (dále výběr), který je detailně a přehledně charakterizován v tabulce č. 1 (z tabulky jsou zřejmé i tzv. podvýběry velikost firmy, odvětví podnikání). Jeho rozsah je dostatečně velký.

Tabulka č. 1: Charakteristika výzkumného souboru

\begin{tabular}{|c|c|c|}
\hline \multirow[t]{2}{*}{ Odvětví } & \multicolumn{2}{|l|}{ Procento } \\
\hline & Velké organizace & Střední organizace \\
\hline Zpracovatelský průmysl & $36 \%$ & $19 \%$ \\
\hline Stavebnictví & $10 \%$ & $8 \%$ \\
\hline Obchod & $8 \%$ & $7 \%$ \\
\hline $\begin{array}{ll}\text { Činnost } & \text { v oblasti } \\
\text { nemovitostí } & \end{array}$ & $9 \%$ & $3 \%$ \\
\hline CELKEM & $63 \%$ & $37 \%$ \\
\hline
\end{tabular}

Zdroj: Vlastní zpracování na základě údajů výzkumu

\section{Výsledky výzkumu}

V následující kapitole jsou postupně popsány a analyzovány výsledky jednotlivých dotazníkových položek. 


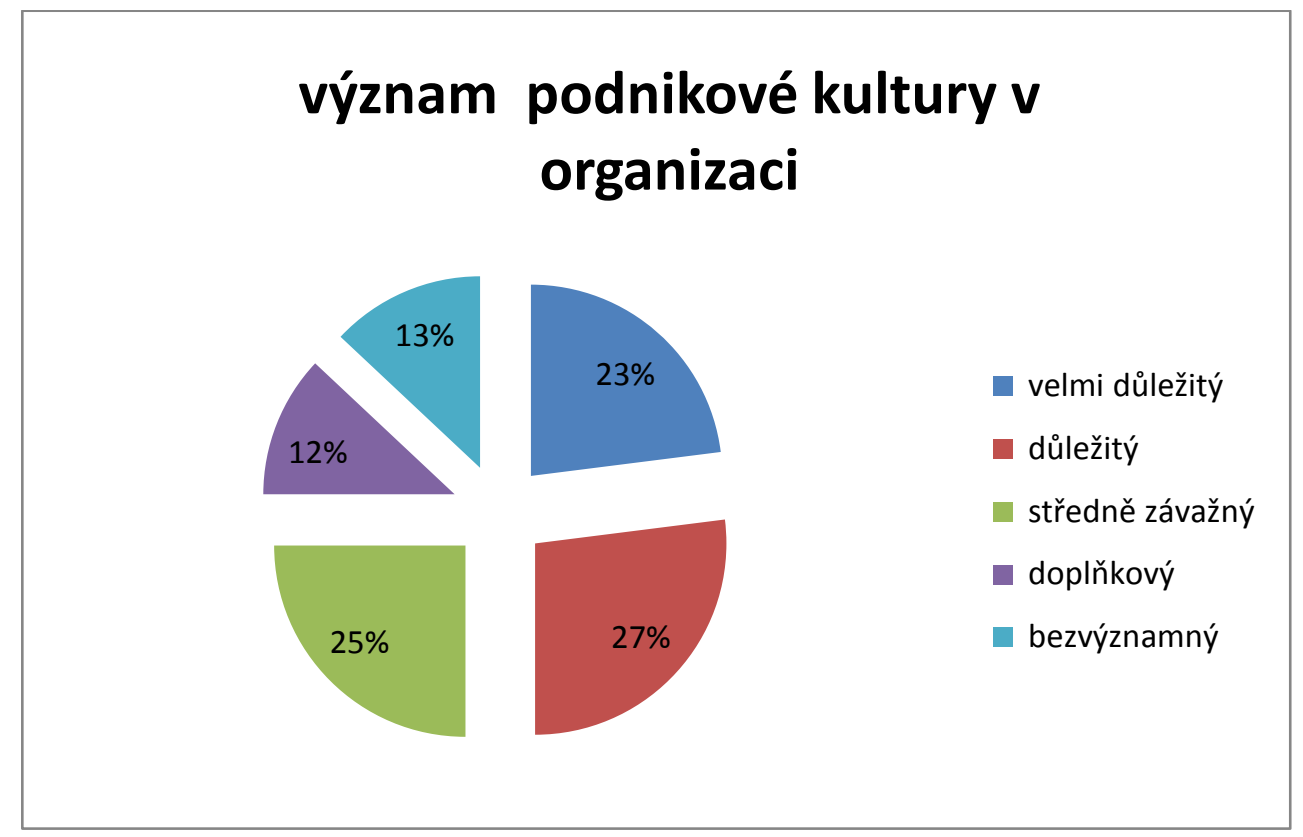

Graf 1: Jak hodnotíte význam podnikové kultury ve vaší organizaci?

Zdroj: Vlastní zpracování na základě údajů výzkumu

Z výpovědí respondentů týkající se významu podnikové kultury v organizaci jasně vyplývá, že podniková kultura má důležitý význam. 75 \% respondentů vnímá podnikovou kulturu jako důležitý atribut organizace. Naopak čtvrtina organizací význam podnikové kultury vnímá jako doplňkový $(12 \%)$ a bezvýznamný $(13 \%)$. Většina $(9 \%)$ respondentů, která nepřikládá podnikové kultuře význam, patřila mezi střední firmy. 


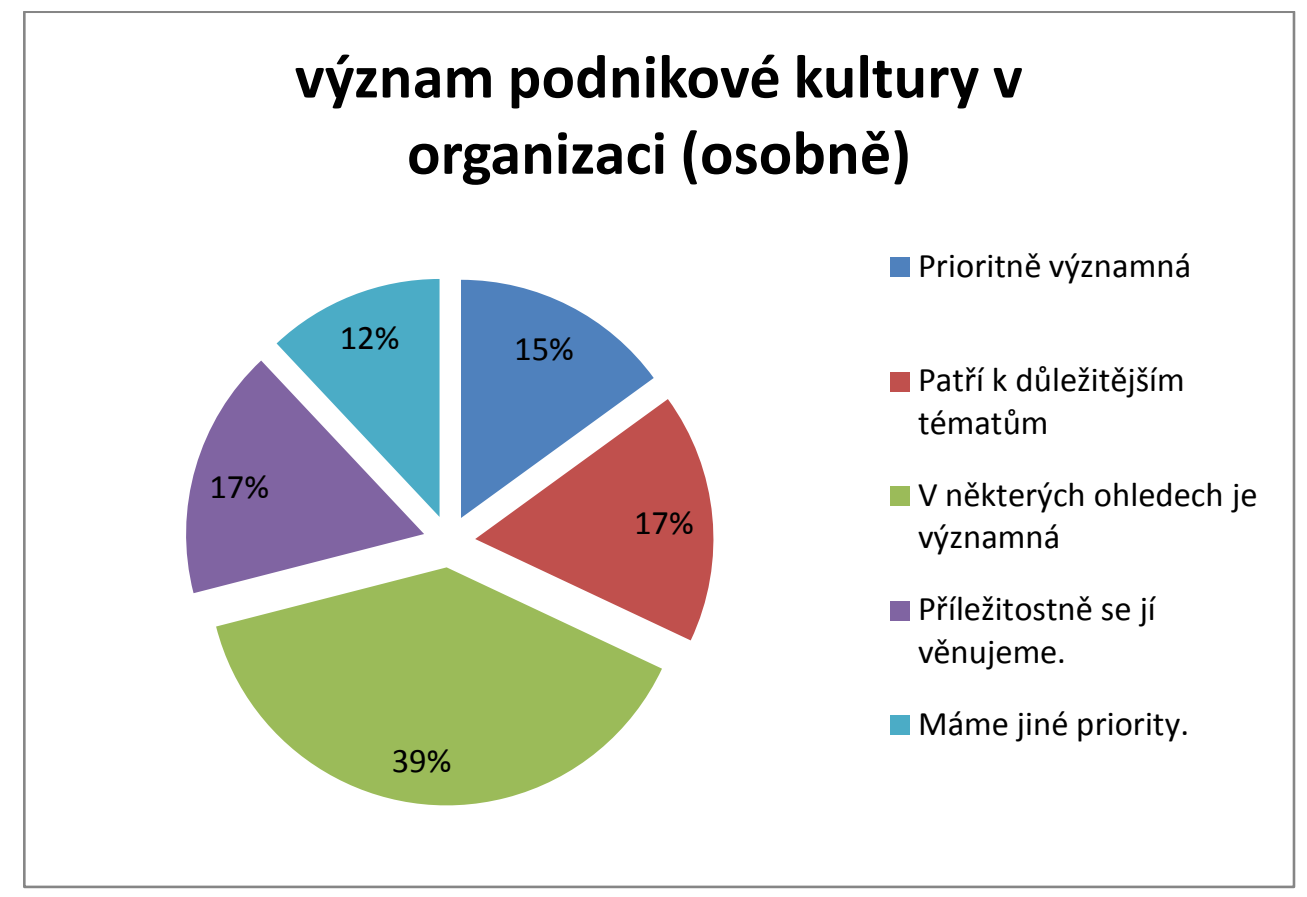

Graf 2: Jak významná je pro Vás osobně oblast podnikové kultury

Zdroj: Vlastní zpracování na základě údajů výzkumu

Následující otázka zkoumala, jaký význam má oblast podnikové kultury pro respondenty osobně. Téměř nejmenší část respondentů (15\%) se domnívá, že patří k důležitým tématům. $\mathrm{O}$ něco více firem $(17 \%)$ chápe kulturu v některých ohledech za významnou. Nejčastěji se respondenti ztotožnili z možností, že podniková kultura je významná v některých ohledech. Nejmenší část (12\%) připustila, že mají jiné priority než podniková kultura. 17 \% přiznává, že se podnikatelské kultuře věnují př́iležitostně. Většina $(19 \%)$ respondentů, kteří osobně přikládají podnikatelské kultuře význam, pracuje ve velkých mezinárodních podnicích, kde se setkávají s různými kulturními rozdíly. 


\section{formulace hodnot ve strategických dokumentech}
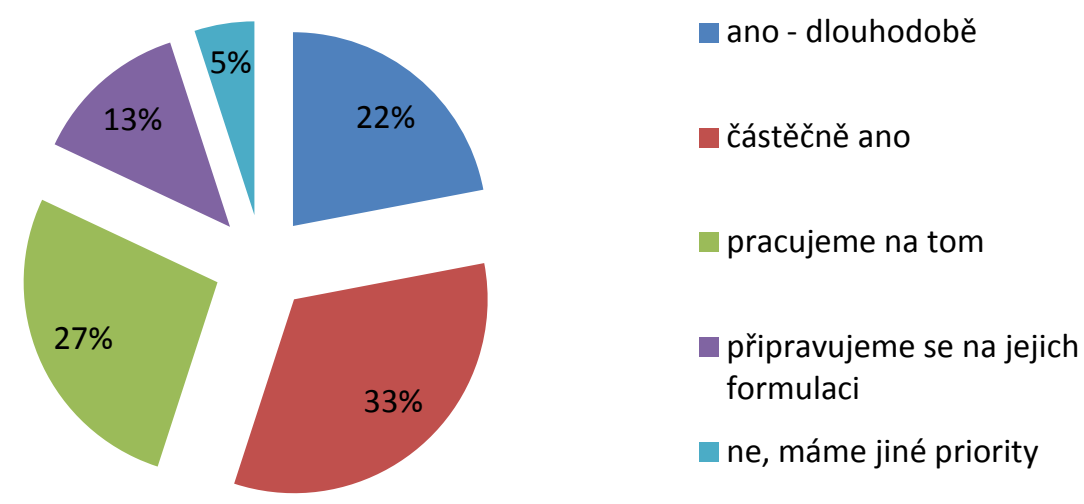

Graf 3: Jsou hodnoty výslovně formulovány ve strategických podnikových dokumentech? Zdroj: Vlastní zpracování na základě údajů výzkumu

Více než polovina respondentů (55 \%) odpověděla, že má ve strategických podnikových dokumentech formulované hodnoty dlouhodobě $(22 \%)$ nebo je má zapracovány částečně (33\%). Čtvrtina organizací (27\%) pracuje na tom, aby hodnoty formulovala do svých podnikových dokumentů. Část $(13 \%)$ si uvědomuje nutnost vymezit hodnoty, proto se připravuje na jejich formulaci. Nepatrné procento $(5 \%)$ nemá hodnoty formulované, protože má jiné priority.

Význam hodnot v podnikové kultuře

\section{význam hodnot v podnikové kultuře}

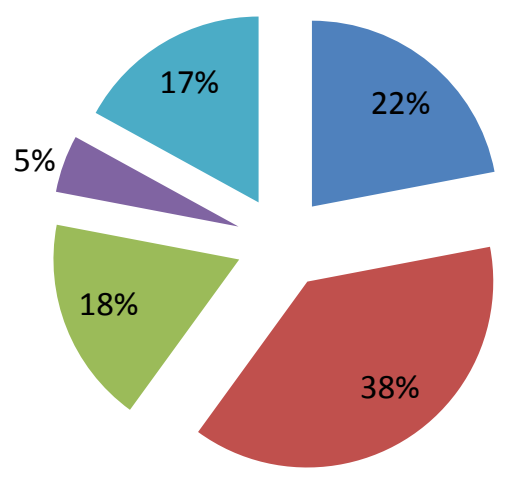

- klíčový

důležitý

podpůrný

okrajový

neutrální

Graf 4: Jaký význam mají firemní hodnoty v podnikové kultuře

Zdroj: Vlastní zpracování na základě údajů výzkumu 
Z následujícího grafu je patrné, že většina (38\%) pokládá hodnoty v podnikové kultuře za důležité. Významná část $(22 \%)$ považuje hodnoty za klíčové. Další respondenti $(18 \%)$ vnímají hodnoty jako podpůrný nástroj v podnikové kultuře. Z odpovědí vyplynulo, že 17 \% respondentů má k hodnotám neutrální postoj. Pouze $5 \%$ chápe hodnoty za okrajové. Zajímavostí bylo, že čím nebezpečnější pracoviště bylo, tím více si organizace zakládala na hodnotách, především na bezpečnosti a ochraně zdraví zaměstnancủ a ochraně životního prostředí.

\section{Klíčové hodnoty}

\begin{tabular}{|l|l|} 
Hodnota & $\%$ \\
\hline Odpovědnost & $19,2 \%$ \\
\hline Dův̌ra & $16,1 \%$ \\
\hline Prosperita & $16,0 \%$ \\
\hline Spravedlnost & $14,3 \%$ \\
\hline Svoboda & $12,1 \%$ \\
\hline Pokrok & $11,2 \%$ \\
\hline Bezpečnost & $11,1 \%$ \\
\hline
\end{tabular}

Tabulka č. 2 Klíčové hodnoty

Zdroj: Vlastní zpracování na základě údajů výzkumu

Výsledků dotazníkového šetření viz. tab. č. 2 vyplývá, že největší část (19, 2 \%) respondentů pokládá odpovědnost na nejdůležitější hodnotu. Shodně $(16 \%)$ vidí jako důležitou hodnotu důvěru a prosperitu. Hodnota spravedlnosti se umístila uprostřed tabulky se 14, $3 \%$. Dále následovala svoboda $(12,1 \%)$, pokrok $(11,2 \%)$ a bezpečnost $(11,1 \%)$.

Je zajímavé, že spravedlnost a svoboda se umístili v polovině, protože většina autorů tvrdí, že spravedlnost a svoboda vytváří prostředí demokratické společnosti, která je otevřená pro podnikání. Na prvním místě se umístila odpovědnost a na druhém důvěra, které jsou základem všech smluvních vztahů, čímž vytváŕí základ pro správnou konkurenci. Pokrok a prosperita jsou velmi úzce propojeny, vyjadřují úspěšnost podniku. Velmi často souvisí s inovacemi. Na posledním místě se umístila bezpečnost, tato hodnota vychází z respektu vůči lidskému životu.

\section{Závěr}

Tento článek definuje pojem organizační kultura a vzestup popularity organizační kultury v posledních desetiletích. Také jsem se zaměřila na prrínos pozitivní organizační kultury. V dnešním globálně-konkurenčním obchodním prostředí, je pozitivní organizační kultura jednou z možností úspěchu firmy. Už jen konkurenční výhoda, se stala předpokladem pro úspěch, což umožňuje společnostem získávat a udržet si špičkové zaměstnance. Chápání organizační kultury a její vliv na chování zaměstnanců, může mít velmi pozitivní dopad na zaměstnance. 
Což dokazují výsledky výzkumu, organizační kulturu mají dobře zpracovanou a uplatňovanou velké podniky, čímž byla potvrzena hypotéza 1. Velmi důležitými faktory, které přispívají k utváření kultury, jsou hodnoty. Mohou to být hodnoty individuální, sdílené, ekonomické, sociální, politické, morální či etické. Hodnoty jsou srdcem každé organizační kultury. V článku bylo poukázáno na výsledky výzkumu, ve kterém firmy označily hodnoty v pořadí: odpovědnost, důvěra, prosperita, spravedlnost, svoboda, pokrok, bezpečnost. Dobře definované hodnoty posilují nejen organizační kulturu, nýbrž mohou přispět ke zkvalitnění fungování každé společnosti a stávají se hlavním identifikačním znakem organizace. Z výsledku výzkumu vyplynulo, že střední a velké firmy pozitivně vnímají význam podnikatelské kultury, tím byla zamítnuta hypotéza 2. Firmy považují hodnoty za klíčové a významné, prričemž hodnoty jsou pro ně důležitou součástí organizační kultury. Úroveň hodnot, organizační kultury je mezi firmami Jihomoravského kraje velmi dobrá, s mírnými rozdíly v závislosti na velikosti firmy, kdy především velké firmy s mezinárodní majetkovou účastí kladou na tuto oblast korporátního řízení zvýšenou pozornost. Na druhou stranu je zajímavým zjištěním, že firmy v Jihomoravském kraji nevnímají organizační kulturu jako významný zdroj konkurenční výhody (hypotéza 3 potvrzena), což ve vztahu k očekávanému makroekonomickému vývoji v ČR i zahraničí vytváří prostor pro další pokračování výzkumu zaměřenou přímo na tuto oblast.

\section{Literatura}

[1] AHMED, P. K., LOH, A.Y.E., ZAIRI, M.Cultures for continuous improvement and learning. In: Total Quality Management. 1999, Vol. 4, No. 10, pp. 26-34.

[2] CLEMENTE, M. N., GREENSPAN, D. S. Culture clashes. In: Executive Excellence. 1999, Vol. 16, No. 10, pp.12.

[3] BLAŽEK, L. Konkurenční schopnost podniků : (primární analýza výsledků empirického šetření). Brno: Masarykova univerzita, 2007. ISBN 978-80-210-4456-2

[4] DEAL, T. E., KENNEDY, A. A. Corporate Cultures: The Rites and Rituals of Corporate Life. Addison-Wesley, Reading, MA, 1982.

[5] DENISON, D, R. Corporate Culture and Organizational Effectiveness. New York: John Wiley, 1990. ISBN 0-471-80021-X.

[6] GOFFEE, R., JONES, G. What holds the modern company together? In: Harvard Business Review. 1996, Vol. 74, No. 6, pp. 33-48.

[7] GREENBERG, J., BARON, R . A. Behavior in Organizations. Prentice-Hall,:Upper Saddle River, NJ, 1997.

[8] GREGER, K. R. A positive corporate culture is the soul of retention. In: Hotel and Motel Management, 1999, Vol. 214, No. 17, pp. 10.

[9] FRANKOVÁ, E. Issues, possibilities and relations of formation of flexibility, creativity and innovation supporting organisational culture. Brno 05.09.2003 - 06.09.2003. In: Business and economic development in central and eastern europe in the period of joining to the european union. Brno: Vysoké učení technické, 2003, pp. 33-37.

[10] LUKÁS̆OVÁ, R. Organizační kultura a její změna. Praha: Grada, 2010. ISBN 978-80247-2951-0.

[11] MALPHURS, A. Values-driven Leadership: Discovering and Developing Your Core Values for Ministry. Baker Books, Grand Rapids, MI, 1996.

[12] NESVADBA, P. Filosofie a etika. Plzeň: Aleš Čeněk, 2006. ISBN 80-86898-92-X.

[13] PUTNOVÁ, A., SEKNIČKA, P. Modelování parametrů CSR jako faktor konkurenceschopnosti firem. 2007. GA402/07/1300 
[14] PUTNOVÁ, A., SEKNIČKA, P., UHLÁŘ, P. Význam společenské odpovědnosti podniku pro efektivní správu společnosti. In: Acta Universitatis Carolinea-Iudidica 3. 2008. Vol. 3. pp. 65-83.

[15] QUBEIN, N. Action takers. In: Executive Excellence. 1999, Vol. 16 No. 10, pp. 4.

[16] RUSSELL, R., F. The role of values in servant leadership. In: Leadership \& Organization Development Journal. 2001, Vol. 22, No. 2 pp. 76-84.

Klasifikace JEL: Z13, Z19

\section{Ing. Lenka Černohorská}

Asistent

Fakulta podnikatelská, Ústav managementu

Vysoké učení technické v Brně,

Kolejní 2906/4, 61200 Brno

cernohorska@fbm.vutbr.cz 